\title{
ゲインスケジューリングを用いた高アスペクト比翼の能動フラッタ制御*1 Active Flutter Suppression of a High-Aspect-Ratio Aeroelastic Using Gain Scheduling
}

\author{
藤 森 篤 ${ }^{* 2} \cdot$ 三 浦 恭 平*3 $\cdot$ 松 下 洸 ${ }^{* 4}$ \\ Atsushi Fujimori, Kyohei Miura and Akira Matsushita
}

Key Words : Active Flutter Suppression, Gain Scheduling, LMI

\begin{abstract}
This paper presents a control design of gain scheduling controllers for active flutter suppression (AFS) in which the closed loop system is stabilized in the operating region specified in advance. The AFS system of a high-aspectratio wing is represented by a linearly interpolated polytopic model whose varying parameter is the dynamic pressure. The gain scheduling controller in this paper consists of a regulator and a full-order observer which are scheduled by the varying parameter. Linear matrix inequalities for designing the gains of the regulator and the observer are separately derived in the frame of the $\mathcal{H}_{2}$ optimization. The control performance and the characteristics of the designed gain scheduling controllers are evaluated in comparison with fixed $\mathcal{H}_{2}$ controllers which are designed with the same design parameters. As the result, the gain scheduling controllers may be inferior to the fixed controller at local regions, but are superior to the fixed controllers for the entire operating region.
\end{abstract}

1. 緒

言

航空機における能動フラッタ抑止 (active flutter suppression : AFS) は, 翼の構造岡性強化による重量増加を招 くことなく，フラッタを抑止しようとするものであり，能動 制御技術の 1 つとして以前から注目されている ${ }^{110)}$. AFS は空力弾性と制御がかわる境界的な問題であり，古くは 空力弾性学のバイブル的な図書 ${ }^{11,12)}$ によって光の概念か紹 介され, 空力, 構造, 制御などの多方面からこれまでに多 くの研究がなされてきた.文献 5)では空力弾性翼のエネル ギーに着目した定性的な検討, 文献 6) ではデル久翼に対し て低次元で高精度なモデル構成法を示している．また，フ ラッタ抑止の制御方法に関する研究として, 最適 (LQG) 制御， $\mathcal{H}_{\infty}$ 制御， $\mu$ などのロバスト制御による方法8)，リ カレントニューラルネットワーク $2 \sim 4,8)$, 可変構造モデル規 範型適用制御9) などの有効性を二次元断面翼や高アスペク 卜比翼を対象として，樣々な飛行環境条件下で検討されて いる.さらに文献 10)では , パイロンなどが付加された翼 に発生する Wing/Store フラッタに対する能動制御が扱わ れている。

著者らもこれまで, 矩形翼や高アスペクト比翼を対象と してモデル同定 ${ }^{13)}$ ，フラッタ振動解析 ${ }^{14)}, \mathrm{AFS}$ 制御系設 計, 13 16) などの検討を試みてきた . 以前の研究 ${ }^{13)}$ では , 高 アスペクト比翼の遷音速域の AFS に関して , 空気力のモデ

\footnotetext{
*1 C) 2007 日本航空宇宙学会

平成 18 年 4 月 11 日原稿受理

*2 山梨大学大学院医学工学総合研究部機械システム工学専攻

*3 静岡大学大学院理工学研究科機械工学専攻

$* 4$ 福井大学大学院工学研究科機械工学専攻
}

ル表現を風洞実験を介することにより改善を图り，光れに 基づいて動圧变化によるモデル化誤差に対してロバストと なる制御器を $\mathcal{H}_{\infty}$ 制御法によって設計して, 光の制御効果 を数值計算および風洞実験で検証した . 帯の結果，フラッ 夕動圧を上昇することは可能であるが, 弚の上昇量は数值 計算では $22 \%$ ，風洞実験では $12 \% に$ 留まった .これは, 設 計された制御器が流れの動圧の上昇に対して安定余裕が少 ないことにより，流れの動圧が制御器を設計した動圧 (設 計点）よりも大きくなるとすぐに不安定化してしまうこと

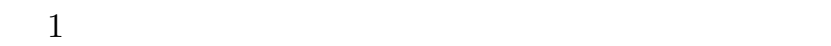
計した制御器は八イゲイン化する傾向があつた . ハイゲイ ン化した制御器の使用においては, 防ぎきれない微小なノ イズや外乱が制御ループに混入することによって操舵面の 発振を誘発してしまうため, 実際には AFS 制御に用いるこ とができなかった ${ }^{13)}$.このことは，制御器ゲインに実質的 な制約があることを意味している。したがって，制御器設計 の設計点を高めに設定すれば見込めるフラッタ動圧の上昇 は高まるが操舵面が発振するリスクが高まる，一方，設計 点を低めに設定すれば発振は回避されるであろうがフラッ 夕動圧の上昇は見込めない，すなわち，フラッタ動圧を向 上させるために制御器の設計点をどこに設定したらより効 果があるのかが明確になっていない .

そこで, 本論文は上記のジレンマを軽減する AFS 制御系 として, 予め設定した動圧変動範囲に対して安定性と性能 を保証するゲインスケジューリング制御について検討する． ゲインスケジューリング制御で設定する動圧範囲は固定ゲ イン制御での設計点ほど直接制御結果に影響してこないで あろうことが予想される . なぜなら, 動圧の変動に応じて 
設計された制御器特性は滑らかに変化するからである．本 研究の制御対象である高アスペクト比翼においては, 制御 器をゲインスケジューリング化することにより，動圧が低 い箇所では低ゲインで動圧が大きくなるにしたがって高ゲ インとなるような制御器特性となるであろうことが予想さ れ，光の結果，固定ゲイン制御よりもフラッタマージンが 確保し易くなると期待できる. 本論文では, 制御対象は遷 音速域での高アスペクト比翼を動圧を可変パラメータとす る線形パラメータ可変 (linear varying parameter : LPV) システムとみなし，これを予め定めた動圧範囲を安定化す る出力フィードバック制御器を， $\mathcal{H}_{2}$ コストを最小化する線 形行列不等式 (linear matrix inequality : LMI) ${ }^{17)}$ に基づ いたゲインスケジューリング法によって設計する . 同じ設計 仕樣を使って $\mathcal{H}_{2}$ 制御法 $^{18)}$ によって設計された固定ゲイン 制御器との比較を通じて , ゲインスケジューリング制御の 有効性をフラッタ動圧の上昇量, 制御性能コス卜 , モデル化 誤差などによって評価する.AFS 制御問題に対するゲイン スケジューリング制御法の適用例としては, 文献 19, 20)な どに見られる.弚こでは, 線形分数表現 (linear fractional trasformation : LFT) を用いた LPV システムとして低次 元近似された制御対象を表現して， $\mu$ 設計およびパラメー 夕依存型の $\mathcal{L}_{2}$ ゲインを評価関数とするゲインスケジューリ ング制御器を設計している．本論文では，より厳密な高次 元制御対象モデルを用いて制御器設計を試みる.制御器設 計においては線形補間型のポリトープモデルで近似表現し

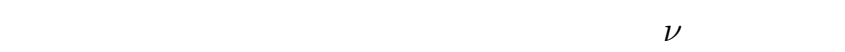
離 $^{21)}$ によって評価しながらモデルの妥当性およびロバスト 安定性を評価している．また本論文では, 同一次元オブザー バをベースとしたゲインスケジューリング制御器構造を採 用することにより一度に解くべき LMI 変数の数を大幅に 低減し, 高次元系に対する LMI の求解性を改善している.

\section{2. 高アスペクト比翼の線形モデル}

本研究で考える高アスペクト比翼を第 1 図に示す . この 翼は民間航空機の翼形状をスケールダウンさせたもので, 翼 スパン長は $1043[\mathrm{~mm}]$, 翼根でのコード長が $369[\mathrm{~mm}]$, 翼 端では $101[\mathrm{~mm}]$ ，約 17 [deg] の後退角が付けられている 翼の状態を測定するセンサは, 曲げや捩りを計測するため に 7 個所に歪ゲージが張られている.また， 4 箇所に加速 度計を取り付けている.制御舵面として, 前縁舵面 $\delta_{1}$ と後 縁舵面 $\delta_{2}$ を装備しており，翼に内蔵されている 2 つの高性 能の $\mathrm{AC}$ サーボモータにより光れ舫れ独立に駆動すること ができる.本研究では, 制御舵面として後縁舵面のみを用 いる. また, AFS 制御器設計では加速度計 $a_{2}$ を翼の出力 として使用する.

翼の弾性変形を $N$ 個の振動モード $\xi \in \mathcal{R}^{N}$ と後縁舵面 $\delta_{2}$ によって表現すると，高アスペクト比翼の空力弾性方程 式は

$$
M \ddot{\xi}(t)+D \dot{\xi}(t)+K \xi(t)+S \ddot{\delta}_{2}(t)=F(q)
$$

と表せる2,22).ただし， $M, D, K \in \mathcal{R}^{N \times N}$ は主翼部

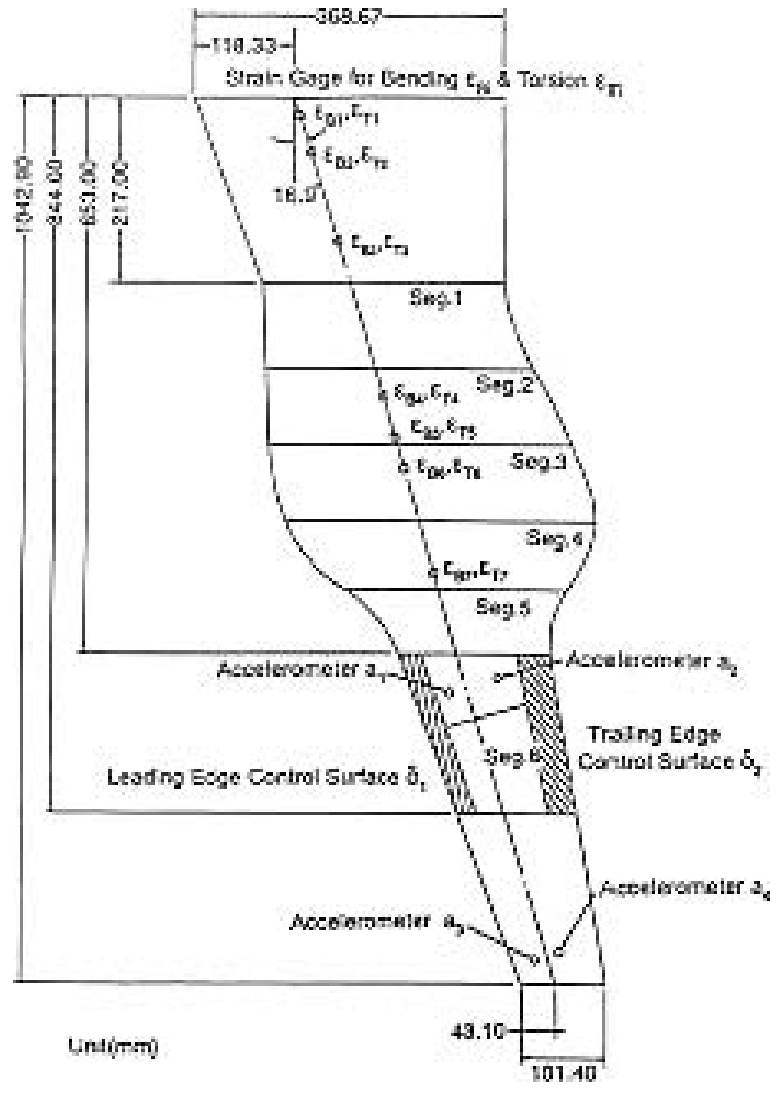

第 1 図 高アスペクト比翼

の質量行列，減衰行列およひ岡性行列である. $S \in \mathcal{R}^{N \times 1}$ は制御舵面の質量行列， $F(q) \in \mathcal{R}^{N}$ は翼の運動に伴う非 定常空気力ベクトルで動圧 $q$ の関数である.

高アスペクト比翼の線形モデルを得るためには , 式 (1) 右辺の空気力 $F(q)$ を， $\xi や \delta_{2}$ に関して線形となるように 近似しなければならない . 本研究は DPM (Doublet Point Method) ${ }^{23)}$ で求めた空気力を次式によって近似する.

$$
\begin{aligned}
F(q)= & A_{2 \xi} \ddot{\xi}+A_{2 \delta} \ddot{\delta}_{2}+\sqrt{q} A_{1 \xi} \dot{\xi}+\sqrt{q} A_{1 \delta} \dot{\delta}_{2} \\
& +q A_{0 \xi} \xi+q A_{0 \delta} \delta_{2}+d \\
\dot{d}=\Lambda d & +q^{3 / 2} B_{0 \xi} \xi+q^{3 / 2} B_{0 \delta} \delta_{2}
\end{aligned}
$$

$A_{i \xi}, A_{i \delta}, B_{0 \xi}, B_{0 \delta}$ は空気力係数行列,$d \in \mathcal{R}^{N}$ は非定 常空気力の遅れを表す補助変数， $\Lambda \in \mathcal{R}^{N \times N}$ は兴の時定 数を集めた行列である.

舵面の駆動系のダイナミックスは次の 2 次系モデル

$$
\ddot{\delta}_{2}+2 \zeta \omega_{n} \dot{\delta}_{2}+\omega_{n}^{2} \delta_{2}=\omega_{n}^{2} \delta_{c}
$$

で与えられる . また , 加速度計の出力に対するアンチ・エ リアッシング・フィルタと $\mathrm{A} / \mathrm{D}$ 変換の時間遅れのダイナ ミックスを考慮する必要がある．乥れらを 1 次系モデル

$$
\begin{aligned}
G_{f}(s) & =\frac{\omega_{f}}{s+\omega_{f}} \\
G_{d}(s) & =\frac{s-\omega_{d}}{s+\omega_{d}}
\end{aligned}
$$

で与える .式(1)〜 (6) をまとめると, 高アスペクト比翼は 
動圧 $q$ を可変パラメータとする 1 入力 1 出力 $3 N+4$ 次元 の LPV システム

$$
\begin{aligned}
& {\left[\begin{array}{l}
\dot{x}_{p}(t) \\
a_{2}(t)
\end{array}\right]=\left[\begin{array}{ll}
A_{p}(q) & B_{p}(q) \\
C_{p}(q) & D_{p}(q)
\end{array}\right]\left[\begin{array}{c}
x_{p}(t) \\
\delta_{c}(t)
\end{array}\right]} \\
& x_{p}(t) \triangleq\left[\begin{array}{llllll}
\xi^{\mathrm{T}} & \delta & \dot{\xi}^{\mathrm{T}} & \dot{\delta} & d^{\mathrm{T}} & \eta^{\mathrm{T}}
\end{array}\right]^{\mathrm{T}} \in \mathcal{R}^{3 N+4}
\end{aligned}
$$

と表現できる. $\eta \in \mathcal{R}^{2}$ は $G_{f}(s)$ と $G_{d}(s)$ を状態空間で表 現した際の状態変数である.より詳細な状態空間表現モデ 儿導出の説明は，文献 22) を参照されたい。

\section{3. ゲインスケジューリング制御系設計}

本節では，AFS のためのゲインスケジューリング出力 フィードバック制御器の設計を示す．制御器設計の拘束条 件がLMI で表現されれば，内点法などを用いた LMI ソル バを用いることにより原理的には解が求められる17)。しか しながら, LMI 変数の数の増加にともなって解の探索領域 か拡大することにより計算時間か増大し, 結果的に求解か困 難なケースが起こり易くなる．前節で示したように，AFS システムは一般に高次元となり易い，乥こで本研究では, 同 一次元オブザーバをべースとしたゲインスケジューリング 制御器構造を用いる. 設計すべき制御器パラメータは制御

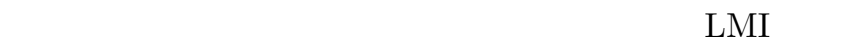
によって設計できる. $\mathcal{H}_{\infty}$ 制御など24,25) に比へてて，一度に 解くべき LMI 变数の数を大幅に低減できる.なお，制御ゲ インとフィルタゲインの設計では, 固定ゲイン制御におけ る最適レギュレータおよび最適オブザーバの簡単な設計プ ロセスを利用するため， $\mathcal{H}_{2}$ コストの最適化問題の LMI 条 件を考える．ただし，本研究での $\mathcal{H}_{2}$ コストは動圧に依存 するため, 最適化においては $\mathcal{H}_{2}$ コストを動作範囲に渡る 積分值を考える．これはすなわち，動作範囲全体に渡る最 適化を考慮したゲインを求めることを意味している.

3.1 制御対象とゲインスケジューリング制御器 AFS 制御器設計のための制御対象を次式の LPV システムとし て与える．

$$
\left[\begin{array}{c}
\dot{x}(t) \\
z(t) \\
y(t)
\end{array}\right]=\left[\begin{array}{ccc}
A(q(t)) & B_{1}(q(t)) & B_{2}(q(t)) \\
C_{1}(q(t)) & 0 & D_{12}(q(t)) \\
C_{2}(q(t)) & D_{21}(q(t)) & D_{22}(q(t))
\end{array}\right]\left[\begin{array}{c}
x(t) \\
w(t) \\
u(t)
\end{array}\right]
$$

$x \in \mathcal{R}^{n_{x}}$ は状態変数, $z \in \mathcal{R}^{n_{z}}$ は制御量,$y \in \mathcal{R}^{n_{y}}$ は観 測出力, $w \in \mathcal{R}^{n_{w}}$ は外部信号, $u \in \mathcal{R}^{n_{u}}$ は制御入力であ る.式(8)は高アスペクト比翼モデル (7) のほかに , 周波 数整形のための周波数依存重み, 設計パラメータなどを含 んで構成されている. 動圧 $q(t)$ は時間 $t$ に依存する. 光の 動作範囲は

$$
q(t) \in[\underline{q}, \bar{q}], \quad \dot{q}(t) \in[\underline{\omega}, \bar{\omega}]
$$

である . LPV システム $(8)$ においては, 動作範囲 $(9)$ にお いて, (i) $\left(A(q), B_{2}(q)\right)$ は可安定 , $\left(C_{2}(q), A(q)\right)$ は可検出 であること , (ii) $\operatorname{rank} D_{12}(q)=n_{u}, \operatorname{rank} D_{21}(q)=n_{y}$ が
成立するものとする .

一方，式 (8) に対するゲインスケジューリング制御器を 次式で与える .

$$
\begin{aligned}
{\left[\begin{array}{c}
\dot{x}_{c}(t) \\
u(t)
\end{array}\right] } & =\left[\begin{array}{cc}
A_{c}(q) & H(q) \\
-F(q) & 0
\end{array}\right]\left[\begin{array}{c}
x_{c}(t) \\
y(t)
\end{array}\right] \\
A_{c}(q) \triangleq & A(q)-B_{2}(q) F(q) \\
& -H(q)\left(C_{2}(q)-D_{22}(q) F(q)\right)
\end{aligned}
$$

$F(q)$ は制御ゲイン,$H(q)$ はフィルタゲイン,$x_{c} \in \mathcal{R}^{n_{x}}$ は制御器の状態変数で $x$ の推定值をも意味する.

制御系設計目的は，LPV システム (8) を動作範囲 (9) に おいて安定化するゲインスケジューリング制御器 (10) を 設計することである .このことは,$A(q)-B_{2}(q) F(q)$ と $A(q)-H(q) C_{2}(q)$ が安定行列であれば ,式 (10)を式 (8) に 代入した閉ループ系の安定性は保証される。よって， $F(q)$ と $H(q)$ は独立して設計できる . $3.3,3.4$ 節では, $\mathcal{H}_{2} コ$ コス 卜最適化をべースとした LMI 条件を満たすように $F(q)$ と $H(q)$ を弚れ光れ設計する。

3.2 制御対象のポリトープモデル LPV システム $(8)$ の各行列には, 動圧 $q$ に関して $q^{1 / 2}, q, q^{3 / 2}$ に依存した 項が含まれているので $q$ に関してアフィンになっていない . $q^{1 / 2}, q, q^{3 / 2}$ を光れ光れ独立な可変パラメータとみなして LFT 表現を用いるなどしてゲインスケジューリング制御器 を設計することも考えられるが，ここではより簡単な方法 として複数の線形時不変 (linear time invariant : LTI) モ デルを用いた補間によって式（8)の各行列を近似表現した ポリトープモデルを構成することを考える . 動作範囲 (9) において $r$ 個の固定した動作点を次式のように選択する .

$$
\underline{q} \leq q_{1}<\cdots<q_{r} \leq \bar{q}
$$

$q=q_{i}$ を式 (8) に代入したものは, $i$ 番目の動作点近傍を 表す局所的な LTI モデルである . これらの局所 LTI モデル 間を線形補間することによって，可変パラメータの動作範 囲全体を表すモデルを構成する．すなわち，式 (8)の各行 列を次式のように与える．

$$
\left[\begin{array}{ccc}
A(q) & B_{1}(q) & B_{2}(q) \\
C_{1}(q) & 0 & D_{12}(q) \\
C_{2}(q) & D_{21}(q) & D_{22}(q)
\end{array}\right]=\sum_{i=1}^{r} \mu_{i}(q)\left[\begin{array}{ccc}
A_{i} & B_{1 i} & B_{2 i} \\
C_{1 i} & 0 & D_{12 i} \\
C_{2 i} & D_{21 i} & D_{22 i}
\end{array}\right]
$$

ただし,$\mu_{i}(q)$ は補間関数であり, 次式で与える

$$
\begin{aligned}
\mu_{1}(q) & = \begin{cases}1 & \left(q \in\left[\underline{q}, q_{1}\right]\right) \\
\phi\left(q ; q_{2}, q_{1}\right) & \left(q \in\left[q_{1}, q_{2}\right]\right) \\
0 & (\text { otherwise })\end{cases} \\
\mu_{i}(q) & = \begin{cases}\phi\left(q ; q_{i-1}, q_{i}\right) & \left(q \in\left[q_{i-1}, q_{i}\right]\right) \\
\phi\left(q ; q_{i+1}, q_{i}\right) & \left(q \in\left[q_{i}, q_{i+1}\right]\right) \\
0 & (\text { otherwise })\end{cases} \\
(i=2, \cdots, r-1) &
\end{aligned}
$$


$\mu_{r}(q)= \begin{cases}\phi\left(q ; q_{r-1}, q_{r}\right) & \left(q \in\left[q_{r-1}, q_{r}\right]\right) \\ 1 & \left(q \in\left[q_{r}, \bar{q}\right]\right) \\ 0 & \text { (otherwise) }\end{cases}$

$$
\phi(x ; a, b) \triangleq \frac{x-a}{b-a}
$$

この $\mu_{i}(q)$ は ,

$$
\begin{aligned}
& 0 \leq \mu_{i}(q) \leq 1 \quad(i=1, \cdots, r) \\
& \sum_{i=1}^{r} \mu_{i}(q)=1
\end{aligned}
$$

を満たす．本論文では，式（13）を用いた式（8）を線形補間 型ポリトープモデルと呼ぶ .

$3.3 \boldsymbol{F}(\boldsymbol{q})$ の設計 $F(q)$ は状態フィードバックゲイン として設計することができる．したがって，式 (8) におい て $y=x\left(C_{2}=I, D_{21}=0, D_{22}=0\right)$ とし，

$$
u(t)=-F(q) x(t)
$$

を式 (8) に代入した閉ループ系

$$
\begin{aligned}
& {\left[\begin{array}{l}
\dot{x}(t) \\
z(t)
\end{array}\right]=\left[\begin{array}{cc}
A_{F}(q) & B_{1}(q) \\
C_{F}(q) & 0
\end{array}\right]\left[\begin{array}{l}
x(t) \\
w(t)
\end{array}\right],} \\
& A_{F}(q) \triangleq A(q)-B_{2}(q) F(q), \\
& C_{F}(q) \triangleq C_{1}(q)-D_{12}(q) F(q)
\end{aligned}
$$

の $\mathcal{H}_{2}$ コストを全動作範囲 (9) に渡って積分したものを最 小化するように設計する．これを行列不等式で表現すると

$$
\begin{aligned}
& \inf _{F, P, W} \int_{\underline{q}}^{\bar{q}} \operatorname{tr} W(q) \mathrm{d} q \text { subject to } \\
& {\left[\begin{array}{cc}
P(q) & P(q) B_{1}(q) \\
(\star) & W(q)
\end{array}\right]>0,} \\
& {\left[\begin{array}{cc}
\operatorname{He}\left(P(q) A_{F}(q)\right)+\dot{q} \frac{\mathrm{d} P}{\mathrm{~d} q} & (\star) \\
C_{F}(q) & -I_{q}
\end{array}\right]<0}
\end{aligned}
$$

となる．ただし， $\mathrm{He}(A) \triangleq A+A^{\mathrm{T}},(\star)$ は対称要素の転 置であることを意味する $. P(q)>0$ はパラメータ依存の Lyapunov 変数である . 行列不等式 (20) を有限個の LMI とするために, 以下の操作を行う . まず, $X(q) \triangleq P^{-1}(q)$, $M(q) \triangleq F(q) X(q)$ と変数変換する $. A(q), B_{1}(q), B_{2}(q)$, $C_{1}(q), D_{12}(q)$ は式 (13) を用いる.また， $X(q), M(q)$, $W(q)$ も同樣の線形補間によって与える.すなわち ,

$$
\begin{aligned}
& X(q)=\sum_{i=1}^{r} \mu_{i}(q) X_{i} \\
& M(q)=\sum_{i=1}^{r} \mu_{i}(q) M_{i} \\
& W(q)=\sum_{i=1}^{r} \mu_{i}(q) W_{i}
\end{aligned}
$$

とする .さらに, $\mathrm{d} P / \mathrm{d} q$ は

$$
\begin{aligned}
& \frac{\mathrm{d} P}{\mathrm{~d} q}=-X^{-1} \frac{\mathrm{d} X}{\mathrm{~d} q} X^{-1} \\
& \frac{\mathrm{d} X}{\mathrm{~d} q} \simeq \frac{X_{i+1}-X_{i}}{q_{i+1}-q_{i}} \triangleq \frac{\Delta X_{i}}{\Delta q_{i}} \quad \text { for } \quad q \in\left[q_{i}, q_{i+1}\right]
\end{aligned}
$$

と近似できる . 行列不等式 (20) の左右から $\operatorname{diag}\{X, I\}$ を 掛けて式 (13)，(21)〜 (23) の線形補間表現を用いると，行 列不等式 (20)の十分条件として次の LMI 条件か導ける .

$$
\begin{aligned}
& \inf _{M_{i}, X_{i}, W_{i}} \sum_{i=1}^{r-1} \operatorname{tr}\left(W_{i} \Delta q_{i}\right) \quad \text { subject to } \\
& {\left[\begin{array}{cc}
X_{i} & B_{1 i} \\
(\star) & W_{i}
\end{array}\right]>0 \quad(i=1, \cdots, r),} \\
& {\left[\begin{array}{cc}
\operatorname{He}\left(A_{i} X_{i}-B_{2 i} M_{i}\right)-\omega \frac{\Delta X_{i}}{\Delta q_{i}} & (\star) \\
C_{1 i} X_{i} D_{12 i} M_{i} & -I_{q}
\end{array}\right]<0,} \\
& {\left[\begin{array}{cc}
\operatorname{He}\left(A_{j} X_{j}-B_{2 j} M_{j}\right)-\omega \frac{\Delta X_{i}}{\Delta q_{i}} & (\star) \\
C_{1 j} X_{j} D_{12 j} M_{j} & -I_{q}
\end{array}\right]<0,} \\
& {\left[\begin{array}{ccc}
\operatorname{He}\left(A_{i} X_{j}-B_{2 i} M_{j}+A_{j} X_{i}-B_{2 j} M_{i}\right)-2 \omega \frac{\Delta X_{i}}{\Delta q_{i}} & (\star) \\
C_{1 i} X_{j}-D_{12 i} M_{j}+C_{1 j} X_{i}-D_{12 j} M_{i} & -2 I_{q}
\end{array}\right]<0} \\
& (i=1, \cdots, r-1, \quad j=i+1), \quad \omega=\underline{\omega}, \quad \bar{\omega}
\end{aligned}
$$

上記を満たす $M_{i}, X_{i}, W_{i}(i=1, \cdots, r)$ が見つかったと き, $F(q)$ は次式で求められる .

$$
F(q)=\left(\sum_{i=1}^{r} \mu_{i}(q) M_{i}\right)\left(\sum_{i=1}^{r} \mu_{i}(q) X_{i}\right)^{-1}
$$

$3.4 \boldsymbol{H}(\boldsymbol{q})$ の設計 状態変数の推定誤差を $e$ とする.す なわち，

$$
e(t) \triangleq x(t)-x_{c}(t)
$$

式 (8)，(10)より，誤差システムは次式で与えられる .

$$
\begin{aligned}
& \dot{e}(t)=A_{H}(q) e(t)+B_{H}(q) w(t) \\
& A_{H}(q) \triangleq A(q)-H(q) C_{2}(q), \\
& B_{H}(q) \triangleq B_{1}(q)-H(q) D_{21}(q)
\end{aligned}
$$

$H(q)$ の設計は, 誤差システム $(29)$ の $\mathcal{H}_{2}$ コストを動作範 囲 (9) に渡って積分したものを最小化するように設計する。 これを行列不等式で表現すると 


$$
\begin{aligned}
& \inf _{H, Q, V} \int_{\underline{q}}^{\bar{q}} \operatorname{tr} V(q) \mathrm{d} q \quad \text { subject to } \\
& {\left[\begin{array}{cc}
Q(q) & (\star) \\
Q(q) & V(q)
\end{array}\right]>0,} \\
& {\left[\begin{array}{cc}
\operatorname{He}\left(A_{H}(q) Q(q)\right)+\dot{q} \frac{\mathrm{d} Q}{\mathrm{~d} q} & B_{H}(q) \\
(\star) & -I_{r}
\end{array}\right]<0}
\end{aligned}
$$

となる. $Q(q)>0$ はパラメータ依存の Lyapunov 変数 である. $F(q)$ の設計と同樣に, 行列不等式 $(30)$ を有限 個の LMI とするための操作を行う. $Y(q) \triangleq Q^{-1}(q)$, $N(q) \triangleq Y(q) H(q)$ と変数変換し, $Y(q), N(q), V(q)$ を 次の線形補間によって与える .

$$
\begin{aligned}
& Y(q)=\sum_{i=1}^{r} \mu_{i}(q) Y_{i} \\
& N(q)=\sum_{i=1}^{r} \mu_{i}(q) N_{i} \\
& V(q)=\sum_{i=1}^{r} \mu_{i}(q) V_{i}
\end{aligned}
$$

$\mathrm{d} Q / \mathrm{d} q$ の近似は，式 $(24),(25)$ と同樣である . 行列不等式 (30)の左右から $\operatorname{diag}\{Y, I\}$ を掛けて式 (13)，(31)〜 (33)の 線形補間表現を用いると, (30)の十分条件として次の LMI 条件が導ける。

$$
\begin{aligned}
& \inf _{N_{i}, Y_{i}, Y_{i}} \sum_{i=1}^{r-1} \operatorname{tr}\left(V_{i} \Delta q_{i}\right) \quad \text { subject to } \\
& {\left[\begin{array}{cc}
Y_{i} & (\star) \\
C_{1 i} & V_{i}
\end{array}\right]>0 \quad(i=1, \cdots, r),} \\
& {\left[\begin{array}{cc}
\operatorname{He}\left(Y_{i} A_{i}-N_{i} C_{2 i}\right)-\omega \frac{\Delta Y_{i}}{\Delta q_{i}} & Y_{i} B_{1 i}-N_{i} D_{21 i} \\
(\star) & -I_{r}
\end{array}\right]<0,} \\
& {\left[\begin{array}{cc}
\operatorname{He}\left(Y_{j} A_{j}-N_{j} C_{2 j}\right)-\omega \frac{\Delta Y_{i}}{\Delta q_{i}} & Y_{j} B_{1 j}-N_{i} D_{21 j} \\
(\star) & -I_{r}
\end{array}\right]<0,} \\
& \begin{array}{c}
{\left[\begin{array}{cc}
\operatorname{He}\left(Y_{i} A_{j}-N_{i} C_{2 j}+Y_{j} A_{i}\right. & Y_{i} B_{1 j}-N_{i} D_{21 j} \\
\left.-N_{j} C_{2 i}\right)-2 \omega \frac{\Delta Y_{i}}{\Delta q_{i}} & +Y_{j} B_{1 i}-N_{j} D_{21 i} \\
(\star) & -2 I_{r}
\end{array}\right]<0} \\
(i=1, \cdots, r-1, \quad j=i+1), \quad \omega=\underline{\omega}, \quad \bar{\omega}
\end{array}
\end{aligned}
$$

上記を満たす $N_{i}, Y_{i}, V_{i}(i=1, \cdots, r)$ が見つかったと き, $H(q)$ は次式で求められる.

$$
H(q)=\left(\sum_{i=1}^{r} \mu_{i}(q) Y_{i}\right)^{-1}\left(\sum_{i=1}^{r} \mu_{i}(q) N_{i}\right)
$$

\section{4. 数值シミュレーション}

前節で示したゲインスケジューリング制御器設計を，高 アスペクト比翼の数值モデルに適用する . 同樣の設計パラ メータを用いて $\mathcal{H}_{2}$ 制御法で設計した固定ゲイン制御器の 性能と比較する .

4.1 AFS システムと設計パラメータ 高アスペクト比 翼の弾性変形は，低周波から 4 つの振動モードを考慮した . 谷の固有振動数を第 1 表に示す. AFS システム $(7)$ は，した がって $3 N+4=16$ 次元となる.アクチュエータ (4)の特性 パラメータは, $\omega_{n}=50 \pi[\mathrm{rad} / \mathrm{s}], \zeta=0.7$,式 (5)，(6)の遮 断周波数を乥れ光れ $\omega_{f}=75 \pi[\mathrm{rad} / \mathrm{s}], \omega_{d}=1000 \pi[\mathrm{rad} / \mathrm{s}]$ と与えた。

制御器設計のための LPV システム $(8)$ を, 以下のように して構成した . まず，ノイズや非モデル化弾性モードの影響 が低減するため，閉ループ系の周波数特性に $-40[\mathrm{~dB} / \mathrm{dec}]$ 以上のロールオフ特性を持たせるように，次式の 2 次系の 周波数依存重みを付加した .

$$
W_{o}(s)=\frac{\omega_{o}^{2}}{\left(s+\omega_{o}\right)^{2}}, \quad \omega_{o}=20 \pi[\mathrm{rad} / \mathrm{s}]
$$

また ,式(8)の設計パラメータに関する行列を次式で与えた .

$$
\begin{aligned}
& C_{1}(q)=\left[\begin{array}{c}
I_{n_{x}} \\
0
\end{array}\right], \quad D_{12}(q)=\left[\begin{array}{c}
0 \\
I_{n_{u}}
\end{array}\right], \\
& B_{1}(q)=\left[\begin{array}{ll}
10 I_{n_{x}} & 0
\end{array}\right], \quad D_{21}(q)=\left[\begin{array}{ll}
0 & I_{n_{y}}
\end{array}\right]
\end{aligned}
$$

よって, $\mathrm{LPV}$ システム (8) の次元は, $n_{x}=18, n_{y}=1$, $n_{u}=1, n_{z}=n_{x}+n_{u}=19, n_{w}=n_{x}+n_{y}=19$ となる.

4.2 AFS 制御器の設計と評価方法 上記の設計パラ メータを用いて，ゲインスケジューリング制御器および固 定ゲイン制御器を設計した. 第 2 表に示す 3 種類のケー スを試みた $q_{F}$ は開ループ系のフラッタ動圧を意味し， $q_{F}=25.4[\mathrm{kPa}]$ である.表中の值は $q_{F}$ で除した值を示 している.ゲインスケジューリング制御器設計においては， 第 2 表に示した動作点を選択して線形補間ポリトープモデ ルを構成し，3.3，3.4 節で示した LMI を数值的に解くこと により $F(q), H(q)$ を設計し，ゲインスケジューリング制 御器 (10) を構成した .一方, 固定ゲイン制御器設計では, 第 2 表に示す設計点 $q_{d}$ でLTI モデルを構成し，式 (37) の 仕樣を用いて $\mathcal{H}_{2}$ 最適化法 ${ }^{18)}$ によって制御器を設計した . $q_{d}$ を動作範囲の上限値とした理由は, 本制御対象は動圧の 上昇に対する安定余裕が動圧の減少に対する光れよりも低 くなる傾向がある ${ }^{13)}$ ので, 与えられた動作範囲をできるだ け安定化する固定ゲイン制御器を得るための措置である .

制御器設計に使用したモデルの評価として, (i) LPV シ ステムと設計モデルとの $\nu$ ギャップ距離，制御性能評価と して , (ii) 動作範囲における閉ループ系の $\mathcal{H}_{2}$ コスト, (iii) 閉ループ系のフラッタ動圧を調べた . また，制御器の特性 評価として, (iv) ロバスト安定余裕, ( v) 制御器の周波数 
ゲインスケジューリングを用いた高アスペクト比翼の能動フラッタ制御 (藤森 篤・三浦恭平・松下 洸)

第 1 表＼cjkstart高アスペクト比翼の固有振動モード

\begin{tabular}{cc}
\hline 振動モード & 固有振動数 $[\mathrm{Hz}]$ \\
\hline 1st & 13.1 \\
2nd & 35.7 \\
3rd & 44.6 \\
4th & 85.0 \\
\hline
\end{tabular}

第 2 表 設計ケース

\begin{tabular}{cccc}
\hline & $\begin{array}{c}\text { 動作範囲 } \\
{\left[\underline{q} / q_{F}, \bar{q} / q_{F}\right], \dot{q} / q_{F}}\end{array}$ & $\begin{array}{c}\text { 線形補間ポリトープ } \\
\text { モデル動作点 }\left\{q_{i} / q_{F}\right\}\end{array}$ & $\begin{array}{c}\text { LTI モデル } \\
\text { 設計点 } q_{d} / q_{F}\end{array}$ \\
\hline Case-1 & {$[1.0,1.15], 0.15$} & $\{1.0,1.15\}$ & 1.15 \\
Case-2 & {$[1.0,1.4], 0.2$} & $\{1.0,1.2,1.4\}$ & 1.4 \\
Case-3 & {$[1.0,1.5], 0.1$} & $\{1.1,1.2,1.3,1.4,1.5\}$ & 1.5 \\
\hline
\end{tabular}

表中の動圧值は開ループ系のフラッタ動圧 $q_{F}$ に対する比である .ただし $q_{F}=25.4[\mathrm{kPa}]$.

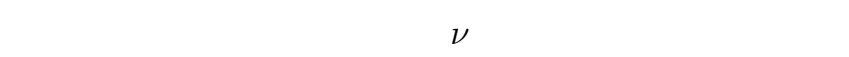
定余裕の定義は以下のとおりである . 2 つの LTI プラント モデルを伝達関数表現で $P_{1}(s), P_{2}(s)$ と表す . このとき， 両者間の $\nu$ ギャップ距離 $\delta_{\nu}\left(P_{1}, P_{2}\right)$ ，すなわち “モデルの ずれ (誤差)”は次式で与えられる ${ }^{21)}$.

$$
\delta_{\nu}\left(P_{1}, P_{2}\right) \triangleq\left\|\left(I+P_{2} P_{2}^{*}\right)^{1 / 2}\left(P_{2}-P_{1}\right)\left(I+P_{1} P_{1}^{*}\right)^{1 / 2}\right\|_{\infty}
$$

$\delta_{\nu}\left(P_{1}, P_{2}\right) \in[0,1]$ であり，大きいほどモデル誤差が大 きいことを意味する.一方，プラントモデル $P_{1}(s)$ を安 定化する LTI 制御器の集合を $\Omega\left(P_{1}\right)$ と表記する . 制御器 $K(s) \in \Omega\left(P_{1}\right)$ の安定余裕 (ゲイン余裕) $b\left(P_{1}, K\right)$ は, 次 式のように定義される ${ }^{21)}$.

$$
b\left(P_{1}, K\right) \triangleq\left\|\left[\begin{array}{c}
K \\
I
\end{array}\right]\left(I-P_{1} K\right)^{-1}\left[\begin{array}{ll}
-P_{1} & I
\end{array}\right]\right\|_{\infty}^{-1}
$$

$b\left(P_{1}, K\right) \in[0,1]$ であり大きいほど安定度が高いことを意 味する.この安定余裕の定義は, 制御対象と制御器の伝達 関数を正規既約分解で表現し, 多变数系のナイキストの安 定判別を適用して定義されたものである ${ }^{21,26)}$. これらを用 いると, 制御器 $K \in \Omega\left(P_{1}\right)$ が $K \in \Omega\left(P_{2}\right)$ となるための 十分条件の 1 つは，

$$
b\left(P_{1}, K\right)>\delta_{\nu}\left(P_{1}, P_{2}\right)
$$

を満たすことである ${ }^{21)}$.これを本研究に適用するには，

$$
\begin{aligned}
P_{2}(s) & \rightarrow P_{\mathrm{lpv}}(s, q) \\
P_{1}(s) & \rightarrow \begin{cases}P_{\mathrm{lti}}(s) & (\text { 固定ゲイン制御 }) \\
P_{\mathrm{poly}}(s, q) & (\text { ゲインスケジューリング制御) }\end{cases} \\
K(s) & \rightarrow \begin{cases}K_{\mathrm{fix}}(s) & (\text { 固定ゲイン制御 }) \\
K_{\mathrm{gs}}(s, q) & (\text { ゲインスケジューリング制御) }\end{cases}
\end{aligned}
$$

と置き替えればよい.ただし， $P_{\mathrm{lpv}}(s, q)$ は可変パラメータ が $q$ での LPV システム , $P_{\mathrm{lti}}(s)$ は固定ゲイン制御では設 計点での LTI モデル, $P_{\text {poly }}(s, q)$ は線形補間ポリトープモ デル, $K_{\mathrm{fix}}(s)$ は固定ゲイン制御器， $K_{\mathrm{gs}}(s, q)$ はゲインス ケジューリング制御器である.

4.3 設計結果および考察 第 $2 \sim 4$ 図に, 動圧の変化に 伴う $\nu$ ギャップ距離を示す. 閉ループ系の $\mathcal{H}_{2}$ コストの変 化を示す. 固定ゲイン制御器設計で用いた LTI モデルは， 動圧か設計点を外れると が , 線形補間型ポリトープモデルではどのケースでも最高

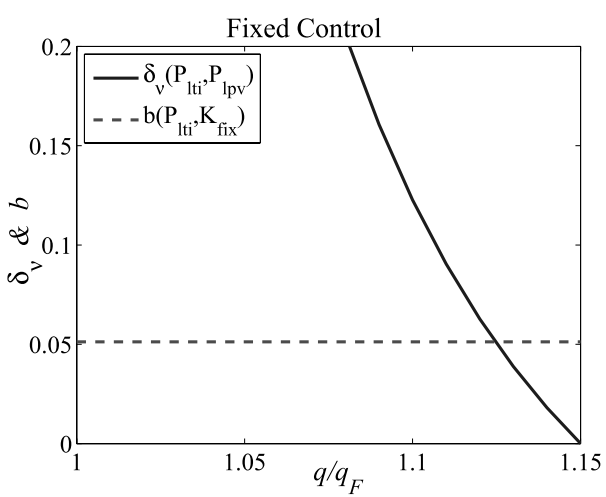

(a) 固定ゲイン制御

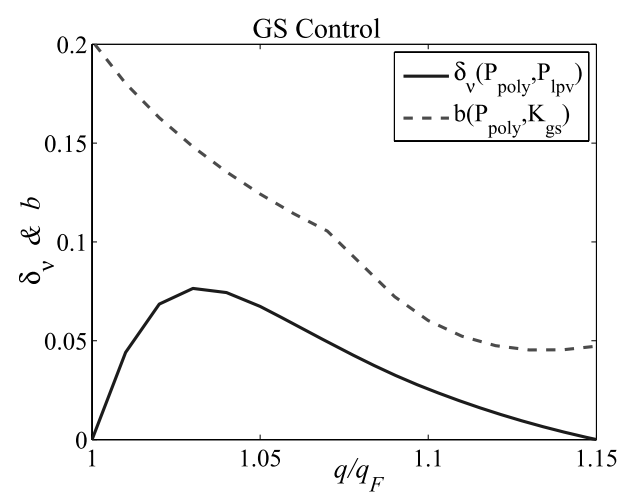

(b) ゲインスケジューリング制御

第2図 $\nu$ ギャップ距離と安定余裕, Case-1

0.11 未満に抑えられている.このことから，線形補間型ポ リトープモデルは LPV システムの妥当な近似モデルであ るといえる . 同図には安定余裕も示されている . 線形補間 型ポリトープモデルを用いたゲインスケジューリング制御 系は, 動作範囲全体に渡ってロバスト安定条件 (40) が満た されている。

第 5〜7 図に,動圧の変化に伴う閉ループ系の $\mathcal{H}_{2}$ コ ストの変化を示す．"Fix” は固定ゲイン制御系，"GS” は ゲインスケジューリング制御系の場合を示す . Case-1 に おいては, どちらの制御器を用いても設定した動作範囲 $q \in\left[1.0 q_{f}, 1.15 q_{F}\right]$ に渡って有限値の $\mathcal{H}_{2}$ コストが求めら れており，全動作範囲において制御対象を安定化できてい ることを意味している $q=1.15 q_{F}$ は, 固定ゲイン制御器 の設計点であり，固定ゲイン制御器のほうが $\mathcal{H}_{2}$ コストを 小さくしている.しかし,$q \in\left[1.0 q_{f}, 1.13 q_{F}\right]$ においては, ゲインスケジューリング制御器のほうが低いコストを示し ている . Case- 2 , - 3 においても , 固定ゲイン制御器の設計 点および光れ以上の動圧範囲において固定ゲイン制御器の 


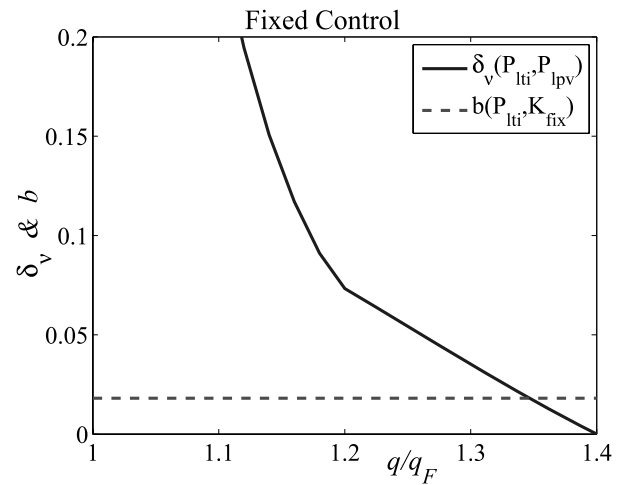

(a) 固定ゲイン制御

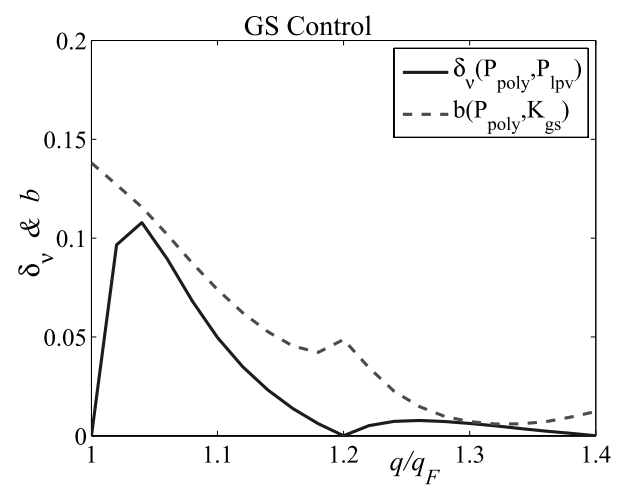

(b) ゲインスケジューリング制御

第 3 図 $\nu$ ギャップ距離と安定余裕, Case-2

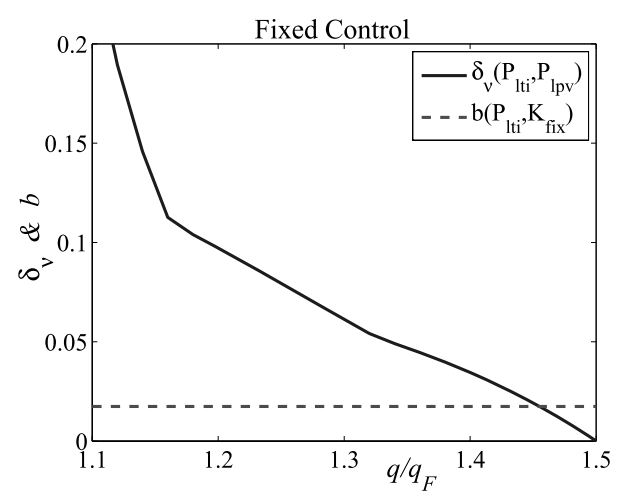

(a) 固定ゲイン制御

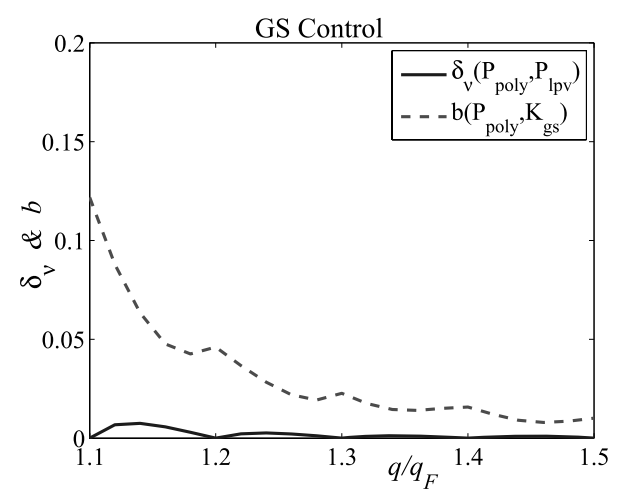

(b) ゲインスケジューリング制御

第4図 $\nu$ ギャップ距離と安定余裕, Case-3

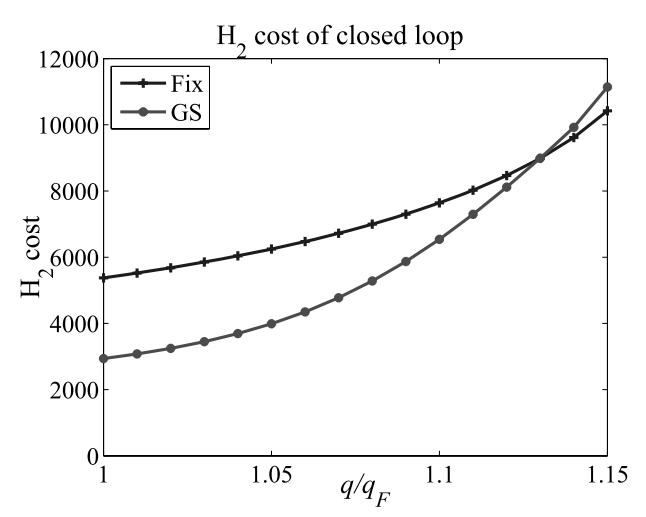

第 5 図 閉ループ系の $\mathcal{H}_{2}$ コスト, Case-1

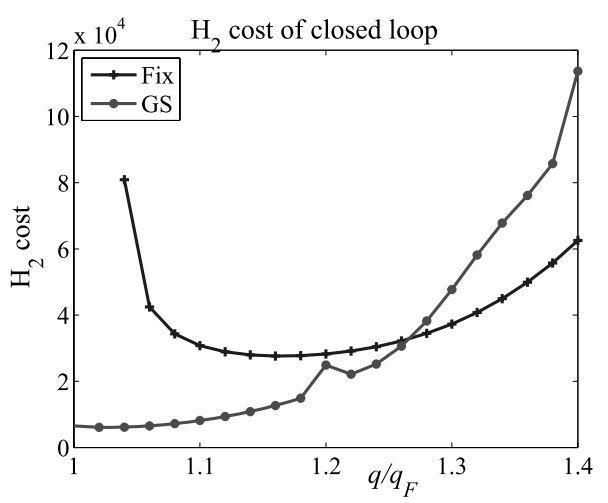

第 6 図＼cjkstart閉ループ系の $\mathcal{H}_{2}$ コスト，Case-2

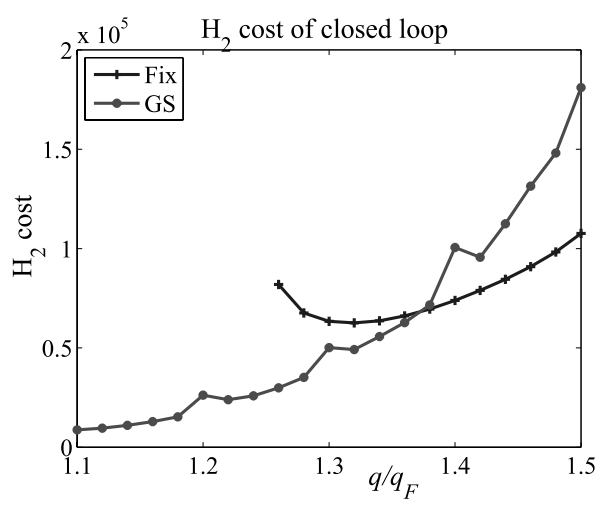

第 7 図 閉ループ系の $\mathcal{H}_{2}$ コスト, Case-3

$\mathcal{H}_{2}$ コストが小さい . しかし , 動作範囲の下限付近におい ては固定ゲイン制御ではコストの上昇が見られ，安定化で きない領域 (曲線か描かれていない $q / q_{F}$ の範囲) もある. 第 $8 \sim 10$ 図に, 制御器の周波数応答を示す. 周波数依存重 みを付加して設計したことにより，どの制御器も高周波数域 において $-40[\mathrm{~dB} / \mathrm{dec}]$ のロールオフ特性を有している．以 前の研究 ${ }^{13)}$ で示されたように，一般に設計点の動圧が上昇 するにしたがって制御器がハイゲインになる傾向がある.ゲ インスケジューリング制御器の場合, Case-1 では動圧の増 加に伴って制御器のゲインが全周波数領域に渡って徐々に上 昇しているのに対して，Case- $2,-3$ では $q \geq 1.3 q_{F}$ におい て $10[\mathrm{~Hz}]$ 以下の低周波で低下する代わりに $100[\mathrm{~Hz}]$ 以上で の高周波でゲインの上昇が見られる .すなわち, $q=1.3 q_{F}$ 

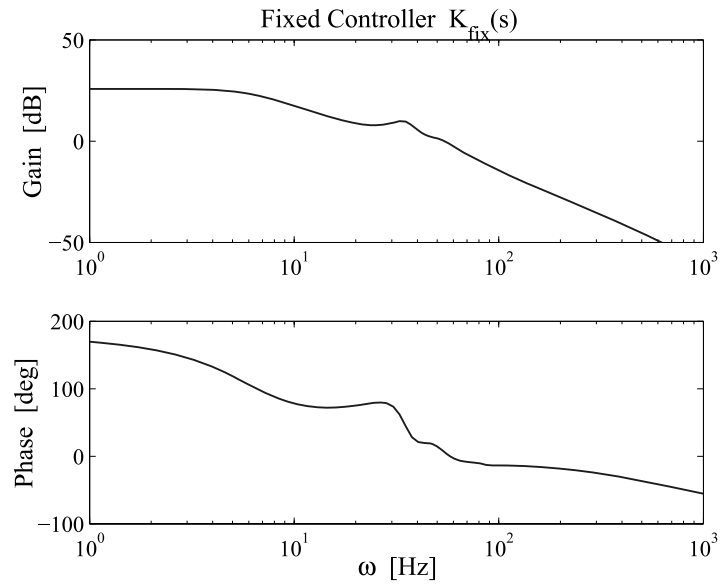

(a) 固定ゲイン制御

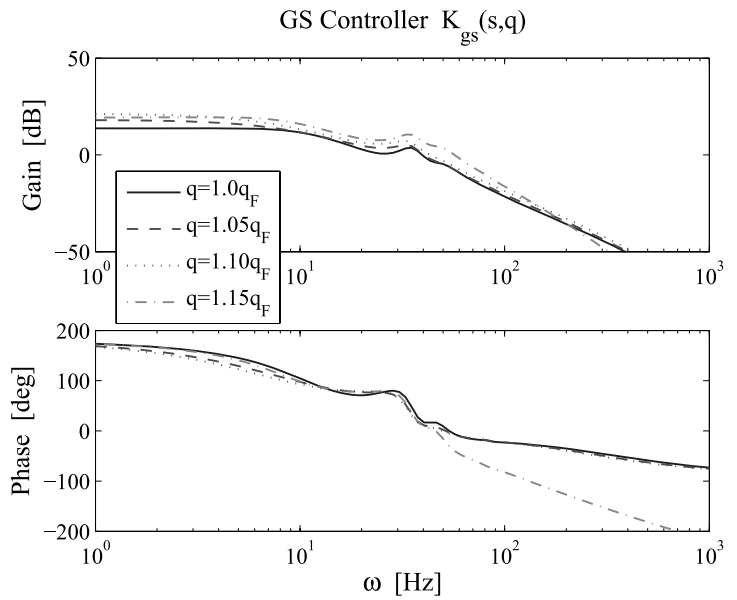

(b) ゲインスケジューリング制御

第 8 図 制御器の周波数応答, Case-1

第 3 表 閉ループ系が安定である動圧範囲

\begin{tabular}{ccc}
\hline & $\begin{array}{c}\text { ゲインスケジュー } \\
\text { リング制御 } \\
{\left[\underline{q} / q_{F}, \bar{q} / q_{F}\right]}\end{array}$ & $\begin{array}{c}\text { 固定ゲイン } \\
\text { 制御 } \\
{\left[\underline{q} / q_{F}, \bar{q} / q_{F}\right]}\end{array}$ \\
\hline Case-1 & {$[0,1.19]$} & {$[0,1.20]$} \\
Case-2 & {$[0,1.47]$} & {$[1.03,1.53]$} \\
Case-3 & {$[0,1.56]$} & {$[1.24,1.59]$} \\
\hline
\end{tabular}

表中の動圧值は開ループ系のフラッタ動圧 $q_{F}$ に 対する比である．ただし， $q_{F}=25.4[\mathrm{kPa}]$.

付近を境にして, 制御器特性が変わっている。一方, 固定 ゲイン制御器の設計点は動圧範囲の上限值に設定したので ゲインスケジューリング制御器の上限值でのゲインとほぼ 同じレベルとなっている．ただし，50[Hz] 以下での固定ゲ イン制御器のゲインはゲインスケジューリング制御器より も高くなる傾向が見られる.

第 3 表に, 閉ループ系でのフラッタ動圧を示す. 安定化 範囲の上限は固定ゲイン制御のほうが若干良いものの, 下 限においてはゲインスケジューリング制御のほうが広い結 果を示している.

以上の結果を総合的に考察する. $\mathcal{H}_{2}$ 最適化によって設計 した固定ゲイン制御器は, 設計動圧において最適な $\mathcal{H}_{2} コ$ ストを示すが，動作範囲全体に対しては必ずしも妥当な制
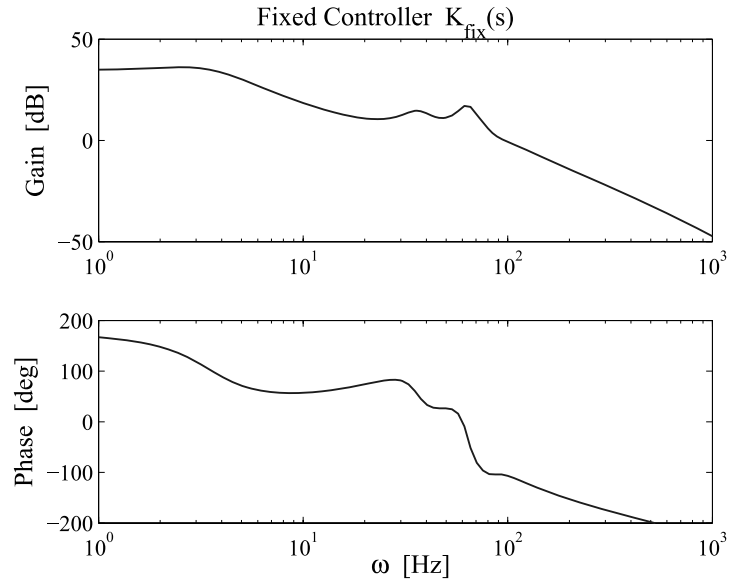

(a) 固定ゲイン制御

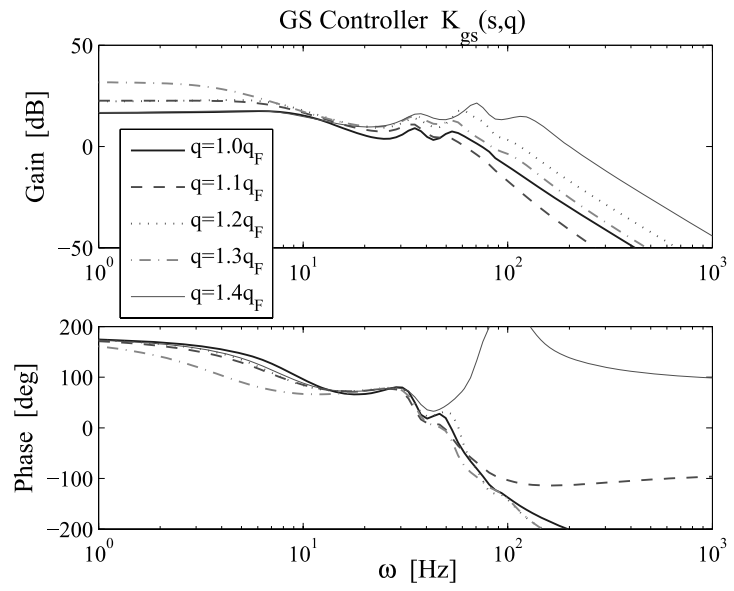

(b) ゲインスケジューリング制御

第 9 図制御器の周波数応答, Case- 2

御器ではない .一方ゲインスケジューリング制御器は, 特定 の動圧点に対しては固定ゲイン制御器に劣ることもあるが， 動作範囲全体について評価した場合は固定ゲイン制御器よ りも好ましい性能を示している．また，ゲインスケジュー リング制御器の周波数特性においても, 動圧変化に応じて ゲインが滑らかに調整取れている．このことは, 操舵面の 発振を回避しながら高めの設計点を選択するという固定ゲ イン制御に比べて柔軟に設計範囲を選び易いことを意味し ている、ただし，第 9,10 图に示すように制御器の周波数 特性は $q=(1.2 \sim 1.3) q_{F}$ 付近を境にして低周波領域での ゲインが低下し, 弚の分高周波で高くなる傾向を示すので， 制御ループでの発振等の観点から好ましくない.よって, 本 研究で扱った高アスペクト比翼の AFS 制御実験システム においては , これ以上の動圧に対してのフラッタ抑止は実 質的には難しいと推測される .

\section{5. 結言}

本論文は, 能動フラッタ抑止のための制御系設計として， 予め設定した動作範囲を安定化する AFS 制御系を設計する 目的で, オブザーバベースドのゲインスケジューリング制 御器設計を LMI を用いて示し, 高アスペクト比翼の AFS 数值モデルを用いて产の設計例を示した . 同樣の設計仕樣 

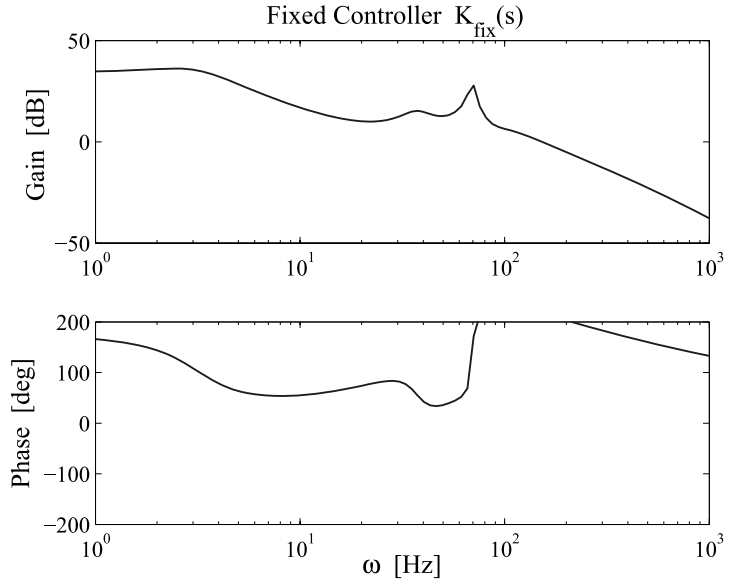

(a) 固定ゲイン制御

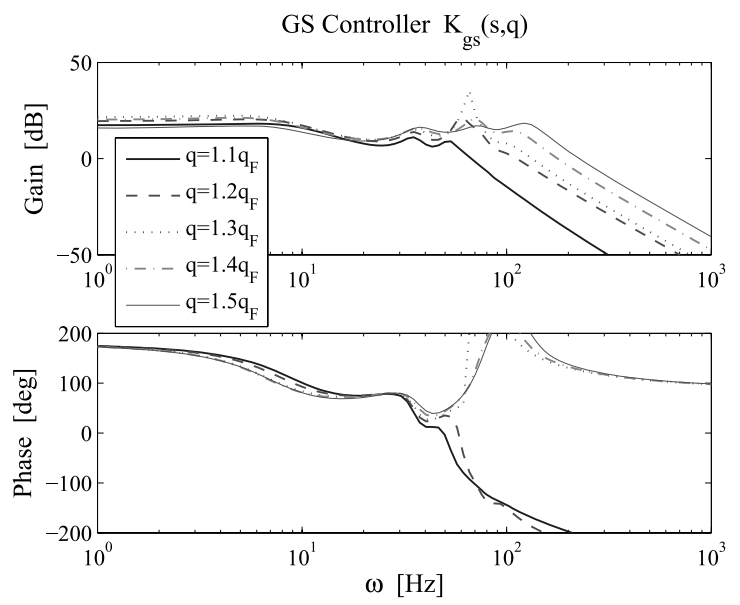

(b) ゲインスケジューリング制御

第 10 図 制御器の周波数応答, Case-3

を用いて固定ゲイン制御器を設計し，制御性能および制御 器の特性を比較評価した . 㚇の結果 , 固定ゲイン制御器は, 設計動圧において最適な $\mathcal{H}_{2}$ コストを示すが, 動作範囲全 体に対しては必ずしも妥当な制御器とはいえない.一方ゲ インスケジューリング制御器は, 特定の動圧に対しては固 定ゲイン制御器よりも劣ることもあるが, 動作範囲全体に ついて評価すれば固定ゲイン制御器よりも好ましい性能を 示した .

本研究では, 数值モデルを用いて AFS のための制御器 としてゲインスケジューリング制御のメリットを示したも のであったが, 実用的な観点から制御器の低次元化 (簡単 化）が必要であり，今後の検討課題である.

\section{参 考 文 献}

1) Bennet, R. M., Eckstrom, C. V., Rivera, J. A., Jr., Dansberry, B. E., Farmer, M. G. and Durham, M. H.: The Benchmark Aeroelastic Models Program-Description and Highlights of Initial Results, NASA TM-104180, 1991.

2) Saitoh, K., Matsushita, H., Hashidate, M. and Baldelli, D. H.: Active Flutter Suppression of a Flexible Wing in Transonic Region, Proc. of Int. Forum on Aeroelasticity and Structural Dynamics, 1994, pp. 581-586.

3) 斉藤健一, 松下 洸, 外立政隆, 鈴木弘一, 安藤泰勝: 高アスペ クト比翼遷音速フラッタのアクティブ制御，第 34 回飛行機シン ポジウム講演集 , 1996, pp. 533-536.
4) Saitoh, K., Baldelli, D. H., Matsushita, H. and Hashidate, M.: Robust Controller Design and Its Experimental Validation for Active Transonic Flutter Suppression, Proc. of Int. Forum on Aeroelasticity and Structural Dynamics, 1997, pp. 393-399.

5) Bendiksen, O. O.: Energy Approach to Flutter Suppression and Aeroelastic Control, J. Guid. Control Dynam., 24 (2001), pp. 176-184.

6) Rule, J. A., Richard, R. E. and Clark, R. L.: Design of an Aeroelastic Delta Wing Model for Active Flutter Control, J. Guid. Control Dynam., 24 (2001), pp. 918-924.

7) Waszak, M. R.: Robust Multivariable Flutter Suppression for Benchmark Active Control Technology Wind-Tunnel Model, J. Guid. Control Dynam., 24 (2001), pp. 147-153.

8) Bernelli-Zazzera, F., Mantegazza, P., Mazzoni, G. and Rendina, M.: Active Flutter Suppression Using Recurrent Neural Network, J. Guid. Control Dynam., 23 (2000), pp. 1030-1036.

9) Zeng, Y. and Singh, S. N.: Output Feedback Variable Structure Adaptive Control of an Aeroelastic System, J. Guid. Control Dynam., 21 (1998), pp. 830-837.

10) Gade, P. V. N. and Inman, D. I.: Two-Dimensional Active Wing/Store Flutter Suppression Using $\mathcal{H}_{\infty}$ Theory, J. Guid. Control Dynam., 20 (1997), pp. 949-955.

11) Fung, Y. C.: An Introduction to the Theory of Aeroelasticity, Wiley, New York, 1955.

12) Bisplinghoff, R. L. and Ashley, H.: Aeroelasticity, AddisonWesley, Cambridge, Mass., 1955.

13) 藤森 篤, 松下 洸, 斉藤健一, 安藤泰勝: 高アスペクト比翼の モデル修正と能動フラッタ抑止，日本航空宇宙学会論文集，48 (2000), pp. 329-335.

14) Matsushita, H., Miyata, T. and Fujimori, A.: Possible Decrement of LOC Flutter Dynamic Pressure Due to Robust Controller, Proc. CD-ROM of 24th ICAS, 2004.

15) 藤森 篤: ロバスト安定性を考慮した補償器の低次元化と二次元 翼能動フラッタ抑止系への応用，日本航空宇宙学会誌，41 (1993), pp. 88-95.

16) 藤森 篤, 中野准也, 太田裕文 : 変動モデル表現に着目した口 バストな能動フラッタ抑止系の設計，日本航空宇宙学会誌，44 (1996), pp. 720-728.

17) Boyd, S., Ghaoui, L. E., Feron, E. and Balakrishnan, V.: Linear Matrix Inequalities in System and Control Theory, Vol. 15, SIAM, Philadelphia, 1994.

18）藤森＼cjkstart篤：ロバスト制御，コロナ社, 東京，2001。

19) Barker, J. M., Balas, G. J. and Blue, P. A.: Gain-Scheduled Linear Fractional Control for Active Flutter Suppression, J. Guid. Control Dynam., 22 (1999), pp. 507-512.

20) Barker, J. M. and Balas, G. J.: Comparing LinearParameter-Varing Gain-Scheduled Control Techniques for Active Flutter Suppression, J. Guid. Control Dynam., 23 (2000), pp. 948-955.

21) Vinnicombe, G.: Uncertainty and Feedback $\left(\mathcal{H}_{\infty}\right.$ LoopShaping and the $\nu$-Gap Metric), Imperial College Press, London, 2001.

22) 松下 洸: 弾性航空機の有限次元モデリングと LQG 制御, SICE セミナーテキスト (実システムのモデリングと制御)，1994, pp. $1-16$.

23) Ueda, T. and Dowell, E. H.: A New Solution Method for Lifting Surfaces in Subsonic Flow, AIAA J., 20 (1982), pp. 348-355.

24) Scherer, C., Gahinet, P. and Chilali, M.: Multiobjective Output-Feedback Control via Optimization, IEEE Trans. Autom. Control, AC-42 (1997), pp. 896-911.

25) Apkarian, P. and Adams, R. J.: Advanced Gain-Scheduling Techniques for Uncertain Systems, Advances in Linear Matrix Inequality Methods in Control, SIAM, Philadelphia, 2000, pp. 209-248.

26) McFarlane, D. C. and Glover, K.: Robust Controller Design Using Normalized Coprime Factor Plant Descriptions, Springer-Verlag, Berlin, 1990. 